Fetal Diagnosis and Therapy

\title{
Intrauterine Blood Transfusion: Current Indications and Associated Risks
}

\author{
Irene T.M. Lindenburg Inge L. van Kamp Dick Oepkes \\ Department of Obstetrics, Leiden University Medical Center, Leiden, The Netherlands
}

\section{Key Words}

Alloimmunization - Chorioangioma · Fetal anemia .

Fetomaternal hemorrhage - Intrauterine blood transfusion . Parvovirus B19 · Perinatal outcome · Procedure-related complications · Sacrococcygeal teratoma - Twin-twin transfusion syndrome

\begin{abstract}
Fetal anemia is a serious complication in pregnancy and associated with perinatal mortality and morbidity. During 25 years of worldwide experience with intravascular intrauterine blood transfusion, a variety of indications have been described. Intrauterine transfusion (IUT) treatment is considered most successful for fetal anemia due to red cell alloimmunization. Moreover, the use of this procedure has also been reported in pregnancies with parvovirus B19 infection, fetomaternal hemorrhage and placental chorioangiomas, for example. This review focuses on the current indications of intrauterine blood transfusions. In addition, we describe the potential complications of IUT treatment.
\end{abstract}

(c) 2014 S. Karger AG, Basel

\section{KARGER}

(c) 2014 S. Karger AG, Base

$1015-3837 / 14 / 0364-0263 \$ 39.50 / 0$

E-Mail karger@karger.com

www.karger.com/fdt

\section{Introduction}

In the early 1960s, intrauterine treatment of fetal anemia due to red cell immunization by percutaneous intraperitoneal transfusion was introduced by Liley. Initially, Liley [1] devised bilirubin extinction in amniotic fluid as a diagnostic tool for fetal alloimmune anemia [2]. At one occasion, erroneously he collected ascites instead of amniotic fluid and this event brought him the idea that intraperitoneal blood transfusion could be an effective method to correct fetal anemia. Fetal position was determined by X-ray to visualize the persistence of swallowed water-soluble contrast medium 'urografin' in the fetal gut, which was combined with fat-soluble contrast medium to visualize the outline of the skin. Under local anesthesia, a needle was inserted into the fetal peritoneum. Although survival rates improved, outcome, especially of hydropic and very young anemic fetuses, remained poor.

The currently used technique, intravascular intrauterine transfusion (IUT) into the umbilical cord, was first described by Rodeck et al. [3] in 1981 using guidance of the needle by fetoscopy. Advances in the resolution of ultrasound enabled pioneers such as Ferdinand Daffos in Paris and Jens Bang in Copenhagen to perform ultra- 
sound-guided cordocentesis and blood transfusion directly into the umbilical vein $[4,5]$. IUT into the intrahepatic portion of the umbilical vein was first described by Nicolini et al. [6] in 1990, and it can be a safe alternative for umbilical cord transfusion in particular in case of a posterior placenta [7]. In the Netherlands, IUT was introduced in 1965 by Bennebroek Gravenhorst et al. [8]. From 1987 onwards, the intravascular technique became the method of choice [9]. Consequently, IUT continues to be the cornerstone of treatment for fetal anemia for a variety of causes. In experienced hands, IUT is now considered a relatively safe procedure. However, complications, even fatal ones, do still occur. This review summarizes the current indications and associated risks of the most successful invasive treatment in fetal medicine.

\section{Data Sources}

The MEDLINE database (http://www.ncbi.nlm.nih. gov/pubmed/) and the Cochrane Library (http://www. cochrane.org/) were used to conduct a literature search to identify relevant articles up until December 2013. The search was restricted to articles published in English. Priority was given to articles reporting results of original research, although review articles and case reports were also included.

\section{Indications for IUT}

Fetal anemia results from the degradation or hemolysis of normal red cells, (temporarily) impaired red cell production, loss or dilution, hemoglobinopathies and erythrocyte membrane or enzymatic disorders. In any fetal disease with severe anemia, intrauterine blood transfusion may be considered. However, as in all invasive procedures in fetal therapy, knowledge of the indication and the underlying disease is important for a successful outcome. The main indication for intrauterine blood transfusion is still fetal anemia due to red cell alloimmunization. Fetal erythrocyte treatment has also been reported to be successful in nonimmune etiology, such as human parvovirus B19 infection, fetomaternal hemorrhage (FMH), twin-twin transfusion syndrome, placental/fetal tumors and other rare diseases (table 1).

The assessment of bilirubin in amniotic fluid was initiated by Liley [2] in 1961 and used to be standard management of red cell alloimmunization in pregnancy. Today, this invasive method has been replaced by serial Doppler determinations of the middle cerebral artery peak systolic velocity (MCA-PSV) in the detection of fetal anemia $[10,11]$. MCA-PSV can be initiated already at 16-18 weeks of gestation. Reliability decreases after 35 weeks of gestation [12]. MCA-PSV has been found to be also useful in identifying fetal anemia in cases of nonimmune hydrops, FMH, chorioangioma, $\alpha$-thalassemia and monochorionic (MC) twins [13].

Most centers perform fetal transfusions up to 35 weeks of gestation, with delivery anticipated at 37-38 weeks. IUT treatment after 32 weeks of gestation might be safer than procedures performed in early gestation and may prolong pregnancy until safe term and improve outcome [14]. However, every IUT carries a risk of procedure-related asphyxia, especially in a compromised fetus. These aspects should be contemplated when considering IUT in advanced gestation, including the assumed risks of an elective delivery.

\section{Red Cell Alloimmunization}

Hemolytic disease of the fetus and newborn (HDFN) results from maternal alloimmunization to red cell antigens, for which mother and fetus are incompatible. Maternal red cell IgG antibodies pass the placenta into the fetal circulation and may cause hemolysis. More than 50 red cell antigens have been associated with HDFN. The most prevalent red cell antibodies are RhD, Kell and Rhc. Other antibodies associated with severe HDFN are antiRh-e/E (Rhesus), Fy(a)/Fy(b) (Duffy blood group), Kidd (Jka) and anti-M (MNS system) $[15,16]$. In the Netherlands, the prevalence of severe HDFN due to maternal alloimmunization to antibodies is $0.05 \%(100 / 200,000$ live-born infants per year).

In the past decade, survival rates after IUT for red cell alloimmunization exceeded $80 \%$ in specialized centers all over the world (table 1). One long-term concern of IUT is that advances in treatment techniques have allowed more hydropic fetuses to survive, and these infants may be at higher risk of long-term morbidity. In a few small studies, the incidence of severe adverse long-term outcome ranges from 2.8 to $13 \%$ [17-19]. Recently, a larger follow-up study (LOTUS study) analyzed outcome after a total of 1,284 IUTs performed in 451 fetuses in a 20 -year period [20]. Alloimmunization was due to $\mathrm{RhD}$ in $80 \%$, Kell in $12 \%$ and Rhc in $5 \%$ of the cases. Twenty-six percent of the fetuses were hydropic at the first transfusion and the mean gestational age at first transfusion was 26 weeks; the mean number of transfusion was 3 . The vast majority ( $>95 \%)$ of children had a normal neurodevelopmental outcome. The major preoperative risk factor for neurodevelopmental 
Table 1. Survival rates per indication for intrauterine blood transfusion

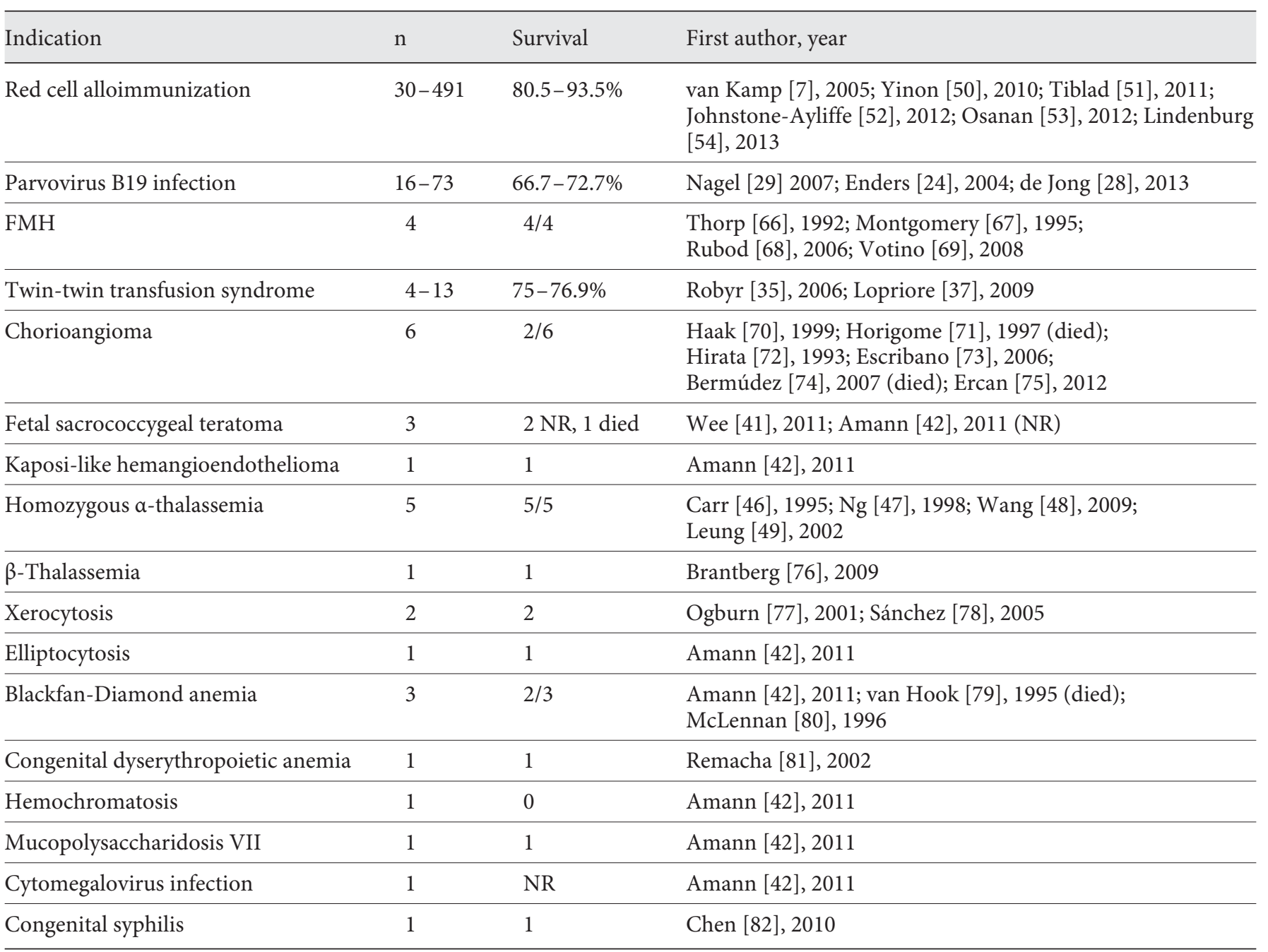

$\mathrm{NR}=$ Not reported

impairment was the presence of hydrops. Prevention of fetal hydrops by timely detection and treatment may improve long-term outcome. The high rate of intact survival confirms the success of IUT for alloimmune anemia.

Intraperitoneal transfusion was first reported by Liley [1] in 1963 and relies on injecting red cells into the peritoneal cavity. These cells are transported through the lymphatic system to the fetal circulation. This absorption may be impeded in case of severe hydrops. A combined intravascular and intraperitoneal approach may allow longer intervals between procedures [21]. Intraperitoneal transfusion may still be a reasonable alternative if attempts to perform intravascular transfusion fail, or in addition to IUT performed in the intrahepatic part of the umbilical vein. Alternatively, in very severely affected pregnancies, with early loss, hydrops or a first IUT $<24$ weeks of gestation in the previous pregnancy, frequent monitoring can be combined with maternal intravenous immunoglobulin (IVIG) administration and/or plasmapheresis in an effort to delay the first IUT and thus reducing the risk for procedural complications $[22,23]$.

A case study reported on 6 women [22] who in previous pregnancies had evidence of severe anemia before 20 weeks of gestation with mortality in 4 of the 6 previous pregnancies. All women received prophylactically serial IUTs between 16 and 21 weeks of gestation combined with adjuvant maternal IVIG in 4/6 cases. Six of the 7 fetuses ( 1 twin) survived, suggesting an advantage of this approach. 
In a series of 9 with a history of fetal hydrops, anemia or fetal demise before 24 weeks of gestation in previous pregnancies, combined therapy with plasmapheresis and IVIG for the treatment of alloimmunization in pregnancy has been applied [23]. Four of the 9 pregnancies had Kell immunization. Plasmapheresis was given every other day, starting after the 12th week of gestation. After the 3rd plasmapheresis, IVIG was administered. All infants survived, and maternal antibody titers were significantly reduced after plasmapheresis and remained decreased during IVIG therapy. The optimal treatment modality for earlyonset severe red cell immunization is not known and provides a challenge for further studies.

\section{Parvovirus B19 Infection}

Human parvovirus B19 is a potent inhibitor of hematopoiesis and may cause bone marrow failure via the involvement of erythroid lineage cells. In $30-50 \%$ of pregnancies infected with parvovirus B19, vertical transmission takes place and leads in $1-2 \%$ to infection of the fetus, which may cause serious fetal morbidity and mortality. A fetus affected by parvovirus B19 may show signs of anemia on ultrasound investigation, such as (severe) hydrops, a hyperdynamic circulation and cardiomegaly. Although spontaneous resolution of fetal anemia due to parvovirus has been described, timely IUT can correct fetal anemia and reduces mortality [24]. In most cases, a single transfusion will lead to recovery. The presence of thrombocytopenia is frequently encountered in fetal parvovirus B19 infection and intrauterine platelet transfusion can be performed relatively safely, although the risk of fluid overload in the hydropic fetus should be weighed against the low incidence of fetal bleeding complications [25]. Perinatal survival after treatment with IUT for fetal anemia due to parvovirus ranges from 67 to $73 \%$ (table 1). Nevertheless, there is a risk for neurological damage, especially in hydropic fetuses, which comprise the majority of cases. This leads to the obvious suggestion that IUT should preferably be done before hydrops develops. In the absence of screening programs for parvovirus susceptibility or infection in pregnant women, the majority is still referred only after the detection of hydrops [26-29].

\section{Fetomaternal Hemorrhage}

$\mathrm{FMH}$ is defined as the passage of fetal blood into the maternal circulation and is a serious rare complication in pregnancy. Massive FMH will lead to severe fetal anemia. Other fetal problems include distress, hydrops, hypovolemic shock and death. These pregnancies often present clinically because of decreased or absent fetal movements.
A Kleihauer test to estimate the volume of hemorrhage and Doppler evaluation of fetal flow velocities (MCAPSV) to detect fetal anemia may aid in disease management [30]. IUT corrects fetal anemia and can prolong gestation until a more mature gestational age is reached. Perinatal death varies between 31 and 50\% [30-32]. The outcome of long-term survivors after severe anemia due to FMH is not well known but includes neurological sequelae [31,32]. de Almeida and Bowman [31] reported the neurological outcome of $15 \mathrm{FMH}$ patients. One infant was diagnosed with cerebral palsy at 6 years of age. Kecskes [32] evaluated the short-term neurological outcome of 16 neonates with demonstrated FMH $>20 \mathrm{ml}$. Five (31\%) had an adverse outcome: death in 3 patients and periventricular leukomalacia in 2 patients. Adverse outcome was better predicted by hemoglobin at birth than by estimated volume of hemorrhage calculated by the Kleihauer test. Whether outcome could be improved by IUT treatment is not known because of the rarity of this disease and the lack of follow-up studies.

\section{Twin-Twin Transfusion Syndrome}

Fetofetal transfusion due to communicating vascular anastomoses in $\mathrm{MC}$ twin pregnancies may result in fetal anemia of the donor twin and polycythemia in the recipient: twin anemia polycythemia sequence (TAPS) [33]. TAPS occurs spontaneously in 3-5\% of MC twin pregnancies and in up to $13 \%$ of twin-twin transfusion syndrome cases treated with laser surgery. There are several management options for TAPS, including IUT, (repeat) laser surgery, elective delivery and expectant management. Treatment with IUT may help to correct the donor twin's anemia, but may potentially deteriorate the plethoric twin's condition $[34,35]$. Therefore, a combination of IUT to the donor with an exchange transfusion in the recipient twin can be considered [36, 37]. Herway et al. [38] performed intraperitoneal IUT with the idea that this technique would not increase the fetal blood pressure and would allow the slow absorption of red blood cells. The best management of TAPS has yet to be determined.

Cerebral injury in TAPS cases treated with or without IUT may be less uncommon than initially thought [39]. Follow-up data on the long-term neurodevelopmental outcome in TAPS are lacking. More studies are necessary to determine whether IUT is a successful option in the management of TAPS.

\section{Placental and Fetal Tumors}

Placental chorioangioma is a vascular tumor of the placenta and occurs in approximately $1 \%$ of pregnancies. 
Most tumors are small and asymptomatic. Large chorioangiomas are clinically significant and may cause serious complications, such as fetal anemia, hydrops and fetal death. Fetal anemia may be a result of FMH (shunting of large volumes of blood to the tumor) and/or hemolysis because of the entrapment and destruction of fetal erythrocytes in the vascular network of the chorioangioma. In the literature, 7 cases of fetal anemia associated with placental chorioangioma treated with IUT have been described (table 1). Treatment with IUT may improve fetal condition and may prevent preterm delivery. Alternative treatment options are (serial) amniodrainage, intratumoral injection of alcohol or pharmacotherapy and feto-/ endoscopic devascularization [40].

Fetal sacrococcygeal teratoma may lead to anemia due either to hemorrhage or hemolysis within the tumor and is associated with poor survival. Three cases with fetal anemia associated with sacrococcygeal teratoma treated with IUT have been described (table 1). Wee et al. [41] presented a fetus with sacrococcygeal teratoma complicated by anemia that received 3 IUTs. Unfortunately, the neonate died shortly after birth. The outcome of the other 2 cases is not reported [42]. Other known fetal interventions are cyst aspiration, amnioreduction, amnioinfusion, open fetal surgical resection [43], radiofrequency ablation or tumor or abdomino-amniotic shunt [44].

Iacovella et al. [45] described the long-term neurodevelopmental outcome of a small cohort of placental and fetal tumors in pregnancy determined by interviews ( 28 chorioangiomas and 10 sacrococcygeal teratomas). The 5 infants with neurodevelopmental delay were all cases of chorioangioma. Abnormal developmental delay may be associated with fetal high-output cardiac failure.

\section{Rare Causes of Fetal Anemia}

Rarely, IUT has also been used to treat severe fetal anemia due to $\alpha$-thalassemia [46-48]. A fetus with homozygous $\alpha$-thalassemia has a gene defect and cannot produce normal fetal hemoglobin but produces $\mathrm{Hb}$ Bart. Bart's fetal hydrops is usually incompatible with extrauterine life. However, antenatal diagnosis and IUT treatment has resulted in some surviving patients, but long-term survival depends on neonatal red cell transfusions and subsequent bone marrow transplantation $[48,49]$.

Other rare causes of fetal anemia treated with IUT have been described (table 1). However, (long-term) outcome data have not always been reported. It is still unknown whether IUT has to be considered in these cases; maybe, successful cases are overrepresented in the literature.

Intrauterine Blood Transfusion

\section{Associated Risks of IUT}

Nowadays, IUT is considered a safe method to correct severe fetal anemia. However, procedural complications sometimes occur and may affect outcome.

\section{Acute Procedure-Related Complications}

Fetal distress during or after the procedure is the most serious complication and may result in fetal death or emergency delivery with the risk of prematurity, neonatal asphyxia or death. Fetal distress can occur after local cord accidents (rupture, spasm, tamponade from a hematoma or excessive bleeding), volume overload, chorioamnionitis, preterm rupture of membranes or preterm labor [ 7 , 50-54].

Fetal demise after intrauterine treatment may be the result of an already compromised fetal state or due to the invasive procedure itself. In the literature, procedurerelated fetal loss ranges from 0.9 to $4.9 \%$ per procedure $[7,50-54]$ and was found to be associated with fetal hydrops $[54,55]$, early gestational age $[50,51]$, failing to use fetal paralysis during IUT [7], transfusion at a free loop of cord or arterial puncture [7, 52], experience of the operator [52, 56] and severity of fetal anemia [53]. Interestingly, preterm premature rupture of membranes after transfusion appears extremely rare, e.g. $0 \%$ [52], $0.1 \%(1 / 740)$ [7], 1.3\% (4/305) [53], 0.4\% (1/284) [51] and $0.2 \%(1 / 631)$ [50] of cases in the largest series. The incidence rates of chorioamnionitis reported in the literature are $0 \%$ [51], 0.3\% (2/740) [7] and 1.0\% (3/305) [53]. In both cases described by van Kamp et al. [7] in 2005, the bacterium Escherichia coli caused the intrauterine infection. From the low incidence of infection after IUT, routine use of antibiotic prophylaxis at IUT is not advised.

\section{Long-Term Complications}

Neonates treated with IUT require more top-up red blood cell transfusions during the first 6 months of life, which may be explained by the suppression of fetal erythropoiesis $[57,58]$. Red blood cell donor transfusions have a minimal but theoretical risk for anaphylactic reactions and transmission of viral diseases.

IUT, transplacental puncture in particular, is also associated with the formation of new red cell antibodies [59]. Additional antibodies are formed by small FMH after IUT. The prevalence of additional maternal red cell antibodies is $19-26 \%$ and may complicate present and subsequent pregnancies and future transfusions $[59,60]$. The presence of additional antibodies causes problems in 
selecting compatible red blood cells for fetal and maternal transfusions, and the antibodies are capable of inducing delayed hemolytic transfusion reactions.

\section{Improving Outcome}

With the use of high-resolution ultrasound to guide invasive obstetric procedures, IUT rapidly became safer. Ultrasonography during IUT is essential for guiding the procedure as well as monitoring of the fetal condition. Fetal distress secondary to local cord accidents may be a result of sudden fetal movements and dislodgment of the needle from its intended site. The use of fetal paralysis may prevent procedure-related fetal loss in $80 \%$ of the cases and thus improve the safety of the procedure $[7,61]$. Even more, prevention of volume overload by adjusting transfusion speed to gestational age, especially in young fetuses and/or hydropic fetuses, may improve outcome $[25,62]$.

Fetal distress may also be associated with (inadvertently) puncturing an artery, causing spasm of the vessel or excessive bleeding at the site of the injection [7]. Although the various points of access to the fetal circulation in relation to fetal loss have not been compared in randomized trials, arterial puncture should therefore be avoided.

The presence of hydrops due to severe anemia is the main prognostic factor affecting survival after IUT therapy $[54,55,63]$. In addition, (alloimmune) fetal hydrops is a major risk factor for long-term neurodevelopmental impairment [20]. Early and timely detection, referral and treatment may prevent hydrops and improve (long-term) outcome. For red cell alloimmunization, universal screening programs have been implemented in most Western countries and aimed at early detection. For fetal infections causing anemia, such as parvovirus B19, no screening programs exist, which means that family doctors, midwives and obstetricians have the responsibility to have a high index of suspicion for this infection in pregnancy and test any pregnant woman with a likely contact with an infected individual.
Avoiding transplacental transfusion, carefully matching the IUT donors for immunogenic antigens, and possibly the use of a single donor serially donating small volumes for 1 particular anemic fetus may prevent the induction of additional antibodies during IUT treatment for alloimmune anemia [58]. However, the mechanism of this immunization phenomenon in pregnant women is still not fully understood [63]. It has been postulated that a high antibody titer during pregnancy together with new antibody formation after IUT were associated with a higher human leukocyte antigen immunization rate or so-called 'high respondership' [64]. The clinical relevance and consequences of leukocyte antibodies are not very clear as both harmful and beneficial effects have been described [65].

\section{Conclusion}

IUT can nowadays be considered a safe and successful method to treat severe fetal anemia for different indications. The two most common indications for intrauterine blood transfusion are fetal anemia due to red cell immunization and parvovirus B19 infection in pregnancy. When considering IUT for fetal anemia due to other (rare) diseases, a careful individual risk-benefit analysis must be made each time. Concerning alternative therapeutic options, no conclusive proof of benefit can be demonstrated. In this respect, centralization of knowledge and skills is of great importance in order to create an optimal management of fetal anemia detected in pregnancy. This indicates the need for an international register to document management, complications and (long-term) outcome of cases.

\section{Disclosure Statement}

We declare no conflicts of interest.

\section{References}

Liley AW: Intrauterine transfusion of foetus in haemolytic disease. Br Med J 1963;ii:11071109.

2 Liley AW: Liquor amnii analysis in the management of the pregnancy complicated by rhesus sensitization. Am J Obstet Gynecol 1961;82:1359-1370.

\footnotetext{
Rodeck CH, Nicolaides KH, Warsof SL, Fysh WJ, Gamsu HR, Kemp JR: The management of severe rhesus isoimmunisation by fetoscopic intravascular transfusion. Am J Obstet Gynecol 1984;150:769-774.

4 Bang J, Bock JE, Trolle D: Ultrasound-guided fetal intravenous transfusion for severe rhesus haemolytic disease. Br Med J 1982;284:373374.
} 
5 Daffos F, Capella-Pavlovsky M, Forestier FA: A new procedure for fetal blood sampling in utero: preliminary results of fifty-three cases. Am J Obstet Gynecol 1983;146:985-987.

-6 Nicolini U, Nicolaidis P, Fisk NM, Tannirandorn Y, Rodeck $\mathrm{CH}$ : Fetal blood sampling from the intrahepatic vein: analysis of safety and clinical experience with 214 procedures. Obstet Gynecol 1990;76:47-53.

7 van Kamp IL, Klumper FJ, Oepkes D, Meerman RH, Scherjon SA, Vandenbussche FP, Kanhai HH: Complications of intrauterine intravascular transfusion for fetal anemia due to maternal red-cell alloimmunization. Am J Obstet Gynecol 2005;192:171-177.

$\checkmark 8$ Bennebroek Gravenhorst J, Kanhai HH, Meerman RH, Ruys JH, Eernisse JG, Stroes TJ, van Nieuwaal K: Twenty-two years of intra-uterine intraperitoneal transfusions. Eur J Obstet Gynecol Reprod Biol 1989;33: 71-77.

-9 van Kamp IL, Klumper FJ, Meerman RH, Oepkes D, Scherjon SA, Kanhai HH: Treatment of fetal anemia due to red-cell alloimmunization with intrauterine transfusions in the Netherlands 1988-1999. Acta Obstet Gynecol Scand 2004;83:731-737.

10 Mari G, Deter RL, Carpenter RL, Rahman F, Zimmerman R, Moise KJ Jr, Dorman KF, Ludomirsky A, Gonzalez R, Gomez R, Oz U, Detti L, Copel JA, Bahado-Singh R, Berry S, Martinez-Poyer J, Blackwell SC: Noninvasive diagnosis by Doppler ultrasonography of fetal anemia due to maternal red-cell alloimmunization. Collaborative Group for Doppler Assessment of the Blood Velocity in Anemic Fetuses. N Engl J Med 2000;342:9-14.

11 Oepkes D, Seaward PG, Vandenbussche FP, Windrim R, Kingdom J, Beyene J, Kanhai HH, Ohlsson A, Ryan G; DIAMOND Study Group: Doppler ultrasonography versus amniocentesis to predict fetal anemia. N Engl J Med 2006;355:156-164.

-12 Zimmerman R, Carpenter RJ, Durig P, Mari G: Longitudinal measurement of peak systolic velocity in the fetal middle cerebral artery for monitoring pregnancies complicated by red cell alloimmunisation: a prospective multicentre trial with intention-to-treat. BJOG 2002;109:746-752.

13 Moise KJ Jr: The usefulness of middle cerebral artery Doppler assessment in the treatment of the fetus at risk for anemia. Am J Obstet Gynecol 2008;198:161.e1-161.e4.

14 Klumper FJ, van Kamp IL, Vandenbussche FP, Meerman RH, Oepkes D, Scherjon SA, Eilers $\mathrm{PH}$, Kanhai $\mathrm{HH}$ : Benefits and risks of fetal red-cell transfusion after 32 weeks gestation. Eur J Obstet Gynecol Reprod Biol 2000;92: 91-96.

15 Koelewijn JM, Vrijkotte TG, van der Schoot CE, Bonsel GJ, de Haas M: Effect of screening for red cell antibodies, other than anti-D, to detect hemolytic disease of the fetus and newborn: a population study in the Netherlands. Transfusion 2008;48:941-952.
16 Moise KJ Jr: Non-anti-D antibodies in redcell alloimmunization. Eur J Obstet Gynecol Reprod Biol 2000;92:75-81.

-17 Farrant B, Battin M, Roberts A: Outcome of infants receiving in-utero transfusions for haemolytic disease. NZ Med J 2001;114:400403.

18 Harper DC, Swingle HM, Weiner CP, Bonthius DJ, Aylward GP, Widness JA: Longterm neurodevelopmental outcome and brain volume after treatment for hydrops fetalis by in utero intravascular transfusion. Am J Obstet Gynecol 2006;195:192.

19 Weisz B, Rosenbaum O, Chayen B, Peltz R, Feldman B, Lipitz S: Outcome of severely anaemic fetuses treated by intrauterine transfusions. Arch Dis Child Fetal Neonatal Ed 2009;94:F201-F204.

20 Lindenburg IT, Smits-Wintjens VE, van Klink JM, Verduin E, van Kamp IL, Walther FJ, Schonewille H, Doxiadis II, Kanhai $\mathrm{HH}$, van Lith JM, van Zwet EW, Oepkes D, Brand A, Lopriore E; LOTUS study group: Longterm neurodevelopmental outcome after intrauterine transfusion for hemolytic disease of the fetus/newborn: the LOTUS study. Am J Obstet Gynecol 2012;206:141.e1-141.e8.

21 Nicolini U, Kochenour NK, Greco P, Letsky $\mathrm{E}$, Rodeck $\mathrm{CH}$ : When to perform the next intra-uterine transfusion in patients with $\mathrm{Rh}$ allo-immunization: combined intravascular and intraperitoneal transfusion allows longer intervals. Fetal Ther 1989;4:14-20.

22 Fox C, Martin W, Somerset DA, Thompson PJ, Kilby MD: Early intraperitoneal transfusion and adjuvant maternal immunoglobulin therapy in the treatment of severe red cell alloimmunization prior to fetal intravascular transfusion. Fetal Diagn Ther 2008;28:159163.

23 Ruma SR, Moise KJ Jr, Eunhee K, Murtha AP, Prutsman WJ, Hassan SS, Lubarsky SL: Combined plasmapheresis and intravenous immune globulin for the treatment of severe maternal red cell alloimmunization. Am J Obstet Gynecol 2007;196:138.e1-138.e6.

24 Enders M, Weidner A, Zoellner I, Searle K, Enders G: Fetal morbidity and mortality after acute human parvovirus B19 infection in pregnancy: prospective evaluation of 1018 cases. Prenat Diagn 2004;24:513-518.

25 de Haan TR, van den Akker ES, Porcelijn L, Oepkes D, Kroes AC, Walther FJ: Thrombocytopenia in hydropic fetuses with parvovirus B19 infection: incidence, treatment and correlation with fetal B19 viral load. BJOG 2008; 115:76-81.

26 Dijkmans AC, de Jong EP, Dijkmans BA, Lopriore E, Vossen A, Walther FJ, Oepkes D: Parvovirus B19 in pregnancy: prenatal diagnosis and management of fetal complications. Curr Opin Obstet Gynecol 2012;24: 95-101.
27 van Klink JM, Koopman HM, Oepkes D, Walther FJ, Lopriore E: Long-term neurodevelopmental outcome after intrauterine transfusion for fetal anemia. Early Hum Dev 2011;87:589-593.

28 de Jong EP, Lindenburg IT, van Klink JM, Oepkes D, van Kamp IL, Walther FJ, Lopriore E: Intrauterine transfusion for parvovirus B19 infection: long-term neurodevelopmental outcome. Am J Obstet Gynecol 2012;206:204.

29 Nagel HT, de Haan TR, Vandenbussche FP, Oepkes D, Walther FJ: Long-term outcome after fetal transfusion for hydrops associated with parvovirus B19 infection. Obstet Gynecol 2007; 109:42-47.

30 Sueters M, Arabin B, Oepkes D: Doppler sonography for predicting fetal anemia caused by massive fetomaternal hemorrhage. Ultrasound Obstet Gynecol 2003;22:186-189.

31 de Almeida V, Bowman JM: Massive fetomaternal hemorrhage: Manitoba experience. Obstet Gynecol 1994;83:323-328.

-32 Kecskes Z: Large fetomaternal hemorrhage: clinical presentation and outcome. J Matern Fetal Neonatal Med 2003;13:128-132.

33 Lopriore E, Middeldorp JM, Oepkes D, Kanhai $\mathrm{HH}$, Walther FJ, Vandenbussche FP: Twin anemia-polycythemia sequence in two monochorionic twin pairs without oligopolyhydramnios sequence. Placenta 2007;28:4751.

34 Nakata M, Sumie M, Murata S, Miwa I, Kusaka E, Sugino N: A case of monochorionic twin pregnancy complicated with intrauterine single fetal death with successful treatment of intrauterine blood transfusion in the surviving fetus. Fetal Diagn Ther 2007;22:7-9.

35 Robyr R, Lewi L, Salomon LJ, Yamamoto M, Bernard JP, Deprest J, Ville Y: Prevalence and management of late fetal complications following successful selective laser coagulation of chorionic plate anastomoses in twin-totwin transfusion syndrome. Am J Obstet Gynecol 2006;194:796-803.

36 Genova L, Slaghekke F, Klumper FJ, Middeldorp JM, Steggerda SJ, Oepkes D, Lopriore E: Management of twin anemia-polycythemia sequence using intrauterine blood transfusion for the donor and partial exchange transfusion for the recipient. Fetal Diagn Ther 2013;34:121-126.

37 Lopriore E, Ortibus E, Acosta-Rojas R, Le Cessie S, Middeldorp JM, Oepkes D, Gratacos E, Vandenbussche FP, Deprest J, Walther FJ, Lewi L: Risk factors for neurodevelopment impairment in twin-twin transfusion syndrome treated with fetoscopic laser surgery. Obstet Gynecol 2009;113:361-366.

38 Herway C, Johnson A, Moise K, Moise KJ Jr: Fetal intraperitoneal transfusion for iatrogenic twin anemia-polycythemia sequence after laser therapy. Ultrasound Obstet Gynecol 2009;33:592-594. 
-39 Lopriore E, Slaghekke F, Kersbergen KJ, de Vries LS, Drogtrop AP, Middeldorp JM, Oepkes D, Benders MJ: Severe cerebral injury in a recipient with twin anemia-polycythemia sequence. Ultrasound Obstet Gynecol 2013; 41:702-706.

-40 Al Wattar BH, Hillman SC, Marton T, Foster K, Kilby MD: Placenta chorioangioma: a rare case and systematic review of literature. J Matern Fetal Neonatal Med 2013, Epub ahead of print.

41 Wee WW, Tagore S, Tan JV, Yeo GS: Foetal sacrococcygeal teratoma: extremes in clinical presentation. Singapore Med J 2011;52:118123.

-42 Amann C, Geipel A, Müller A, Heep A, Ritgen J, Stressig R, Kozlowski P, Gembruch U, Berg C: Fetal anemia of unknown cause - a diagnostic challenge. Ultraschall Med 2011; 32(suppl 2):E134-E140.

43 Hedrick HL, Flake AW, Crombleholme TM, Howell LJ, Johnson MP, Wilson RD, Adzick NS: Sacrococcygeal teratoma: prenatal assessment, fetal intervention, and outcome. J Pediatr Surg 2004;39:430-438.

44 Lee MY, Won HS, Hyun MK, Lee HY, Shim JY, Lee PR, Kim A: Perinatal outcome of sacrococcygeal teratoma. Prenat Diagn 2011;31: 1217-1221.

45 Iacovella C, Chandrasekaran N, Khalil A, Bhide A, Papageorghiou A, Thilaganathan B: Fetal and placental vascular tumors: persistent fetal hyperdynamic status predisposes to poorer long-term neurodevelopmental outcome. Ultrasound Obstet Gynecol 2013, DOI: 10.1002/uog.13272.

46 Carr S, Rubin L, Dixon D, Star J, Dailey J: Intrauterine therapy for homozygous alphathalassemia. Obstet Gynecol 1995;85:876.

$\checkmark 47$ Ng PC, Fok TF, Lee CH, Cheung KL, Li CK, So KW, Wong W, Yuen PM: Is homozygous alpha-thalassaemia a lethal condition in the 1990s? Acta Paediatr 1998;87:1197.

48 Wang C, Ryan G: Transfusion medicine illustrated: intrauterine transfusion for homozygous alpha thalassemia reverses hydrops fetalis. Transfusion 2009;49:1043.

-49 Leung WC, Oepkes D, Seaward G, Ryan G: Serial sonographic findings of four fetuses with homozygous alpha-thalassemia-1 from 21 weeks onwards. Ultrasound Obstet Gynecol 2002;19:56-59.

-50 Yinon Y, Visser J, Kelly EN, Windrim R, Amsalem H, Seaward PG, Ryan G: Early intrauterine transfusion in severe red blood cell alloimmunization. Ultrasound Obstet Gynecol 2010;36:601-606.

- 51 Tiblad E, Kublickas M, Ajne G, Bui TH, Ek S, Karlsson A, Wikman A, Westgren M: Procedure-related complications and perinatal outcome after intrauterine transfusions in red cell alloimmunization in Stockholm. Fetal Diagn Ther 2011;30:266-273.
52 Johnstone-Ayliffe C, Prior T, Ong C, Regan F, Kumar S: Early procedure-related complications of fetal blood sampling and intrauterine transfusion for fetal anemia. Acta Obstet Gynecol Scand 2012;91:458-462.

53 Osanan GC, Silveira Reis ZN, Apocalypse IG, Lopes AP, Pereira AK, da Silva Ribeiro OM, Vieira Cabral AC: Predictive factors of perinatal mortality in transfused fetuses due to maternal alloimmunization: what really matters? J Matern Fetal Neonatal Med 2012;25: 1333-1337.

54 Lindenburg I, van Kamp I, van Zwet E, Middeldorp J, Klumper F, Oepkes D: Increased perinatal loss after intrauterine transfusion for alloimmune anaemia before 20 weeks of gestation. BJOG 2013;120:847-852.

55 van Kamp IL, Klumper FJ, Bakkum RS, Oepkes D, Meerman RH, Scherjon SA, Kanhai $\mathrm{HH}$ : The severity of immune fetal hydrops is predictive of fetal outcome after intrauterine treatment. Am J Obstet Gynecol 2001;185: 668-673.

56 Lindenburg IT, Wolterbeek R, Oepkes D, Klumper FJ, Vandenbussche FP, van Kamp IL: Quality control for intravascular intrauterine transfusion using cumulative sum (CUSUM) analysis for the monitoring of individual performance. Fetal Diagn Ther 2011; 29:307-314.

57 De Boer IP, Zeestraten EC, Lopriore E, van Kamp IL, Kanhai HH, Walther FJ: Pediatric outcome in Rhesus hemolytic disease treated with and without intrauterine transfusion. Am J Obstet Gynecol 2008;198:54.e1-54.e4.

58 Rath ME, Smits-Wintjens VE, Lindenburg I, Brand A, Oepkes D, Walther FJ, Lopriore E: Top-up transfusions in neonates with Rh hemolytic disease in relation to exchange transfusions. Vox Sang 2010;99:65-70.

59 Schonewille H, Klumper FJCM, van de Watering LMG, Kanhai HHH, Brand A: High additional maternal red cell alloimmunization after Rhesus- and K-matched intrauterine intravascular transfusions for hemolytic disease of the fetus. Am J Obstet Gynecol 2007;196: 143.e1-143.e6.

60 Watson WJ, Wax JR, Miller RC, Brost BC: Prevalence of new maternal alloantibodies after intrauterine transfusion for severe Rhesus disease. Am J Perinatol 2006;23:189-192.

61 Dodd JM, Windrim RC, van Kamp IL: Techniques of intrauterine fetal transfusion for women with red-cell isoimmunisation for improving health outcomes. Cochrane Database Syst Rev 2012;9:CD007096.

62 Kamping MA, Pasman SA, Bil-van den Brink CP, Oepkes D, Adama van Scheltema PN, Vandenbussche FP: Fluid shift from intravascular compartment during fetal red blood cell transfusion. Ultrasound Obstet Gynecol 2013;41:550-555.

63 Mesogitis S, Daskalakis G, Pilalis A, Papantoniou N, Antsaklis A: Fetal intravascular transfusion for hydropic disease due to rhesus isoimmunization. Fetal Diagn Ther 2005;20: 431-436.
64 Verduin EP, Schonewille H, Brand A, Haasnoot GW, Claas FH, Lindenburg IT, Lopriore E, Oepkes D, Roelen DL, Doxiadis II: High anti-HLA response in women exposed to intrauterine transfusions for severe alloimmune hemolytic disease is associated with mother-child HLA triplet mismatches, high anti-D titer, and new red blood cell antibody formation. Transfusion 2013;53: 939-947.

65 Lashley EE, Meuleman T, Claas FH: Beneficial or harmful effect of antipaternal human leukocyte antibodies on pregnancy outcome? A systematic review and meta-analysis. Am J Reprod Immunol 2013;70:87-103.

66 Thorp JA, Cohen GR, Yeast JD, Perryman D, Welsh C, Honssinger N, Stephenson S, Hedrick J: Nonimmune hydrops caused by massive fetomaternal hemorrhage and treated by intravascular transfusion. Am J Perinatol 1992;9:22-24.

67 Montgomery LD, Belfort MA, Adam K: Massive fetomaternal hemorrhage treated with serial combined intravascular and intraperitoneal fetal transfusions. Am J Obstet Gynecol 1995;173:234-235.

68 Rubod C, Houfflin V, Belot F, Ardiet E, Dufour P, Subtil D, Deruelle P: Successful in utero treatment of chronic and massive fetomaternal hemorrhage with fetal hydrops. Fetal Diagn Ther 2006;21:410-413.

69 Votino C, Mirlesse V, Gourand L, Parnet-Mathieu F, Bessières B, Daffos F: Successful treatment of a severe second trimester fetomaternal hemorrhage by repeated fetal intravascular transfusions. Fetal Diagn Ther 2008;24: 503-505.

70 Haak MC, Oosterhof H, Mouw RJ, Oepkes D, Vandenbussche FP: Pathophysiology and treatment of fetal anemia due to placental chorioangioma. Ultrasound Obstet Gynecol 1999; 14:68-70.

71 Horigome H, Hamada H, Sohda S, Igari M, Nagata M, Okuno S, Wafa A, Kubo T: Large placental chorioangiomas as a cause of cardiac failure in two fetuses. Fetal Diagn Ther 1997; 12:241-243.

72 Hirata G, Masaki DI, O’Toole M, Medearis AL, Platt LD: Color flow mapping and Doppler velocimetry in the diagnosis and management of a placental chorioangioma associated with nonimmune fetal hydrops. Obstet Gynecol 1993;81:850-852.

73 Escribano D, Galindo A, Arbués J, Puente JM, De la Fuente P: Prenatal management of placental chorioangioma: value of the middle cerebral artery peak systolic velocity. Fetal $\mathrm{Di}$ agn Ther 2006;21:489-493.

74 Bermúdez C, Luengas O, Pérez-Wulff J, Genatios U, García V, Guevara-Zuloaga F, Quintero RA: Management of a placental chorioangioma with endoscopic devascularization and intrauterine transfusions. Ultrasound Obstet Gynecol 2007;29:97-98. 
75 Ercan CM, Coksuer H, Karasahin KE, Alanbay I, Baser I: Combined approach in a large placental chorioangioma case with intratumoral alcohol injection, cordocentesis, IU transfusion, and amnioreduction. Fetal Pediatr Pathol 2012;31:374-378.

-76 Brantberg A, Eik-Nes SH, Roberts N, Fisher C, Wood WG: Severe intrauterine anemia: a new form of beta thalassemia presenting in utero in a Norwegian family. Haematologica 2009;94:1157-1159.
-77 Ogburn PL Jr, Ramin KD, Danilenko-Dixon D, Fairbanks VF, Ramsey PS: In utero erythrocyte transfusion for fetal xerocytosis associated with severe anemia and non-immune hydrops fetalis. Am J Obstet Gynecol 2001;185: 238-239.

78 Sánchez M, Palacio M, Borrell A, Carmona F, Cobo T, Coll O, Cararach V: Prenatal diagnosis and management of fetal xerocytosis associated with ascites. Fetal Diagn Ther 2005;20: 402-405.

79 van Hook JW, Gill P, Cyr D, Kapur RP: Diamond-Blackfan anemia as an unusual cause of nonimmune hydrops fetalis: a case report. J Reprod Med 1995;40:850-854.

-80 McLennan AC, Chitty LS, Rissik J, Maxwell DJ: Prenatal diagnosis of Blackfan-Diamond syndrome: case report and review of the literature. Prenat Diagn 1996;16:349-353.
81 Remacha AF, Badell I, Pujol-Moix N, Parra J, Muñiz-Diaz E, Ginovart G, Sardà MP, Hernández A, Moliner E, Torrent M: Hydrops fetalis-associated congenital dyserythropoietic anemia treated with intrauterine transfusions and bone marrow transplantation. Blood 2002;100:356.

82 Chen I, Chandra S, Singh A, Kumar M, Jain V, Turnell R: Successful outcome with intrauterine transfusion in non-immune hydrops fetalis secondary to congenital syphilis. J Obstet Gynaecol Can 2010;32:861-865. 